\title{
Botany
}

\section{A preliminary investigation of the lichen biota associated with recently deglaciated terrain in southeastern Alaska}

\begin{tabular}{|r|l|}
\hline Journal: & Botany \\
\hline Manuscript ID & cjb-2021-0087.R1 \\
\hline Manuscript Type: & Article \\
\hline Aute Submitted by the & 24-Jun-2021 \\
\hline Complete List of Authors: & $\begin{array}{l}\text { Fryday, Alan; Michigan State University } \\
\text { Dillman, Karen; US Forest Service }\end{array}$ \\
\hline $\begin{array}{r}\text { Keyword: } \\
\text { consideration in a Special } \\
\text { Issue? : }\end{array}$ & $\begin{array}{l}\text { climate change, maritime glaciers, post-glacial succession, prolonged } \\
\text { snow-lie, rare lichen species }\end{array}$ \\
\hline
\end{tabular}

\section{SCHOLARONE \\ Manuscripts}




\title{
A preliminary investigation of the lichen biota associated with recently deglaciated terrain in southeastern Alaska
}

\author{
Alan M. Fryday and Karen L. Dillman
}

Alan M. Fryday: Herbarium, Department of Plant Biology, Michigan State University, East Lansing, MI 48824-1312, USA. ORCID: 0000-0002-5310-9232

Karen L. Dillman: U.S. Forest Service, Alaska Region, Tongass National Forest, P.O. Box 309, Petersburg, AK 99833, USA.

Corresponding author: Alan M. Fryday (email: fryday@msu.edu)

\begin{abstract}
Glaciers worldwide are currently retreating at unprecedented rates, revealing large tracts of newly exposed rock and till. We present the results of a preliminary, qualitative investigation of the lichen diversity of transient habitats near three glaciers in southeastern Alaska: Muir Glacier within Glacier Bay National Park and Baird and Patterson Glaciers in the Tongass National Forest. This work is noteworthy as it; 1) documents previously undescribed lichen species and communities within rapidly changing glacier habitats, 2) illustrates the importance of cryptogams (lichens, bryophytes, algae and cyanobacteria) in the primary colonization of recently deglaciated terrain, 3) sets apart the lichen biota of recently deglaciated terrain in southeastern Alaska from that of other glacial regions worldwide (e.g., the European Alps, Svalbard, and southern South America) and even other parts of Alaska (e.g., Brooks Range) and, 4) emphasizes the importance of more lichen studies that focus on this rapidly changing habitat. The lichen biotas found at different successional stages near these glaciers are described and compared. The role of lichens and other cryptogams in post-glacial vegetation initiation, the threats to the lichen biota, and suggestions for the possible origins of the lichen propagules that colonize these newly exposed surfaces are also discussed.
\end{abstract}

Key Words: climate change, maritime glaciers, post-glacial succession, prolonged snow-lie, rare lichen species.

\section{Introduction}

Southeastern Alaska (also known as the Alaska Panhandle and hereafter referred to as SE Alaska) is a region of particularly active geologic processes that have resulted in an exceptionally rugged mountainous terrain that has been rapidly eroded by glaciation (Gehrels and Berg 1994). The present-day icefields of SE Alaska straddle the Coast Range's highest elevations between the Canadian provinces of British Columbia and Yukon Territory and SE Alaska's Alexander Archipelago, which constitutes most of this remote maritime region. The icefields (Juneau, Stikine, Chickamin and others) and their associated glaciers are the most significant remnants of the vast Cordilleran Ice Sheet, whose retreat period began at least 14,000 years ago (Kaufman and Manley 2004; Briner et al. 2017). Glaciers flow from the 
icefields and into the lowlands through steep fjords carved by ancient ice, terminating at or near sea level most often in a temperate rainforest ecosystem.

Glaciers worldwide are diminishing at unprecedented rates (Marzeion et al. 2014; Zemp et al. 2015; Roe et al. 2017). The glaciers of SE Alaska and the associated icefields are no exception (Arendt 2011; Loso et al. 2014a), and this is due to regional increases in mean air temperature and precipitation changes induced by global climate change (Markon et al. 2018; Lader et al. 2019). The negative impacts of rapid loss of glacial ice are well known and publicized. These include landscape reconfiguration and water availability impacting downstream ecosystems as well as the impacts on society through altered watershed values, compromised fisheries and tourism, and sea-level rise (Larsen et al. 2007; Fell et al. 2017; Cauvy-Fraunié and Dangles 2019). Recent work (Deng et al. 2021) has also shown that the redistribution of mass caused by melting glacial ice is affecting the earth's axis of rotation. However, accelerated deglaciation also facilitates the study of biodiversity in newly exposed terrains. For example, the terminal and lateral moraines left behind from the retreating ice are unique habitats to study vegetation colonization patterns and soil development within a known period.

Investigation of the vegetation of recently deglaciated terrain began in Alaska with the work of Cooper (1923), who detailed vegetation succession of habitats in what is now Glacier Bay National Park and Preserve (NPPr). Cooper recognized three stages of succession: pioneer, alder, and conifer forest, but did not give a time scale for the process. Further work in the same area by Decker (1966), Reiners et al. (1971), Lawrence (1979) and Chapin et al. (1994) refined these stages of succession, identifying between four (Chapin et al. 1994) and eight (Decker 1966) stages and also gave approximate times for the appearance of these stages post-glaciation. Worley (1973) paid particular attention to the early pioneer stage of succession and identified a "black crust" on recently deglaciated soils that was composed of liverworts, cyanobacteria, and the lichen Lempholemma radiatum (Sommerf.) Henssen. Other lichens were mentioned in association with this "black crust" but were not further identified.

Chapin et al. (1994) summarized the previous work on post-glacial succession at Glacier Bay NPPr, describing a pioneer stage, dominated by the "black crust" with scattered forbs (particularly Epilobium latifolium L.), Dryas drummondii Richardson ex Hook., willows (Salix spp.), cottonwood (Populus trichocarpa Torr. and Gay), and spruce (Picea sitchensis (Bong.) Carrière). After c. 30 years, this transitioned to a Dryas stage dominated by swards of Dryas drummondii and persistent individuals of willows (Salix spp.) and alder (Alnus spp.) that, after c. 50 years, became dominant and formed the alder stage of succession with additional conifers initiating. The final stage of the succession that they identified was the development of spruce woodland after c. 100 years. However, it is worth noting that these stages are just nodes along a continuum of constantly evolving vegetation, and that the species composition and the rate of change applies only to this particular locality. Plant communities in post-glacial succession at other localities may contain different species, and 
the succession may proceed at different rates depending upon local climatic and geologic conditions.

None of the studies mentioned above gave more than a cursory mention to lichens and, to the best of our knowledge, apart from a short paper on Mendenhall Valley's lichens by McCullough (1965), the lichen biota of recently deglaciated terrain in SE Alaska is entirely undocumented.

During the summers of 2011 and 2014, the first author visited Muir Glacier in Glacier Bay NPPr as part of an inventory of the lichen biota of the National Park (Spribille et al. 2020), while in 2015, the first and second authors briefly visited Baird and Patterson Glaciers in the Tongass National Forest. The three glaciers experience varying temporal rates of recession, which results in habitats that fall within several different successional stages of vascular plant and lichen community development at any point in time. These visits initiated the first investigations of the early succession lichen biota exposed to the harsh and rapidly changing conditions within the periglacial environment in this region. The data presented here represents the first preliminary assessment of recently deglaciated terrain as a unique and understudied habitat for lichen communities in this temperate rainforest region.

\section{Materials and methods}

At each of the three locations, investigations were conducted for up to 2 days as close as possible to the glacier margin and within the terminal and lateral moraines' most recently exposed areas. Our visits were preliminary "scoping" visits to assess whether the habitat was worthy of further investigation and were of a non-quantitative nature. Due to time and weather constraints, complete species lists were not made, and common species, especially of the macrolichen genera Stereocaulon and Cladonia, were not systematically collected or recorded. However, all but the most common species were noted and others, where it was not possible to identify in the field, were collected. Therefore, nearly all the species characteristic of recently deglaciated terrain would have been accounted for in the areas investigated.

Reaching the forelands of SE Alaskan glaciers is seldom straight-forward. Access is usually only possible by boat and then on foot, usually over rough and steep terrain. Consequently, locations for investigations were dictated by ease of access on foot and by boat, as well as by tide and weather conditions, which can prevent marine or river access. Each glacier and its environs contain a unique geological history, but the commonality among the studied locations across the three areas was a relatively recent terrain exposure due to deglaciation. Thus, the sites we surveyed had all been exposed to less than c. 40 years of icefree conditions, and some were exposed as little as three years before the visit. Microhabitats investigated were sand, gravel, cobble, granitic boulders, bryophyte mats (Muir and Baird Glaciers), calcareous rock outcrops (Patterson Glacier), and less than 40-year-old Alnus viridis (Chaix) DC. ssp. sinuata (Regel) Á. Löve \& D. Löve (Sitka alder) and Picea sitchensis (Bong.) Carrière (Sitka spruce) trees (Patterson Glacier at Garnet Creek). 
The sites varied slightly in climate and precipitation. The community of Petersburg $\left(56.8125^{\circ},-132.956^{\circ}\right)$, which is nearest the Stikine Icefield (Baird and Patterson glaciers) in central SE Alaska, reports average low (December/January) and average high (July/August) temperatures of $3^{\circ} \mathrm{C}$ and $17^{\circ} \mathrm{C}$ respectively, with annual precipitation of $2743 \mathrm{~mm}$ (not including snow) (Western Regional Climate Center, 2021a). The community of Gustavus $\left(58.250^{\circ},-135.420^{\circ}\right)$, nearest to the Muir Glacier, reports mean low (December/January) and high (July/August) temperatures of $-3^{\circ} \mathrm{C}$ and $14^{\circ} \mathrm{C}$ respectively, with an average annual precipitation of $1498 \mathrm{~mm}$ (not including snow) (Western Regional Climate Center, 2021b).

\section{Site Descriptions}

\section{Muir Glacier}

Muir Glacier flows from the Alsek and Chilkat Ranges (within the northern extent of SE Alaska's Coast Range) and terminates at the remote head of Upper Muir Inlet in the eastern arm of Glacier Bay $\left(59.10^{\circ},-136.38^{\circ}\right.$; Fig 1) in Glacier Bay NPPr. Upper Muir Inlet is $10 \mathrm{~km}$ long and was filled with contiguous ice as recently as 1960. Since then, the ice has broken up and retreated rapidly, with the last few kilometers of the inlet becoming ice-free in the early 1980s. Because Muir Glacier is a tidewater glacier (terminates directly into saltwater) (Fig. 2A), we accessed a lateral moraine area adjacent to the glacier on the north side of the inlet to investigate. The site consisted of sand, cobbles, and boulders among thick mats of Dryas drummondii and was interspersed with willow and alder saplings (Fig. 2B). This site is referred to Chapin et al.'s Dryas stage of post-glacial succession.

Approximately $300 \mathrm{~km}$ to the SE of Glacier Bay NPPr, the Baird and Patterson Glaciers flow from the Stikine Icefield. The United States area of the icefield is under the administration of the Department of Agriculture, US Forest Service, Tongass National Forest.

\section{Baird Glacier}

Baird Glacier $\left(57.12^{\circ},-132.80^{\circ}\right.$; Fig. 3) flows into Thomas Bay but is not currently considered a tidewater glacier. The glacier terminates in a lake filled with icebergs from the melting glacier, from which the glacial water flows into saltwater via a short and swift river channel. Centuries of sand and gravel deposition from a relatively stable glacial terminus have formed an extensive outwash plain c. 2 km square (Muir 1915; Viens 2001) of sand, gravel and boulders mainly of granitic geology in front of the terminal moraine (Fig 3A). This outwash plain helps facilitate human access to the most recently deglaciated areas from saltwater by boat and on foot. This relatively intact but dynamic landscape receives periodic flooding, contained mainly in the carved-out water channels, due to glacial outbursts draining supraglacial lakes at higher elevations of the glacier. Unlike other glaciers originating on the Stikine Icefield, which are experiencing rapid recession (including Patterson; Pelto 2013a), the Baird Glacier terminus had been at a relatively stable location for the past 100 years (Viens 2001). Aerial photographs from the 1970s show the glacier terminus over-riding the present-day terminal moraine and an unvegetated outwash plain (NSIDC 2019, Fig. 4). Then, 
c. 2013, a glacial outburst initiated the Baird's terminus to break apart and subsequently retreat very rapidly, revealing more of the sand, gravel and boulders of the terminal moraine (Pelto 2013b). We investigated the lichens present within the cryptobiotic crust communities of the outwash plain (Fig. 3D), which is referable to Chapin et al.'s Dryas stage and early succession cryptobiotic crust and siliceous rock communities in the pioneer stage on the terminal moraine (Figs 3B \& C).

\section{Patterson Glacier}

Patterson Glacier $\left(56.95^{\circ}-132.65^{\circ}\right.$; Fig 5) currently terminates in a deep inland lake (Patterson Lake) at c. $100 \mathrm{~m}$ above sea level that flows into Patterson River and eventually Thomas Bay approximately $6 \mathrm{~km}$ downstream. The lake and steep fjord surrounding it prevents foot access to the lateral moraines adjacent to the glacier (Fig. 5A). Due to the inaccessibility of the areas nearest the ice on foot, a deglaciated side valley containing a creek that flows into the lake about $0.8 \mathrm{~km}$ south of the glacier terminus, known locally as Garnet Creek, was instead surveyed $\left(56.939^{\circ},-132.6525^{\circ}\right.$; Fig. 5B). Old maps and aerial photos indicate that the Patterson Glacier once served as a dam to glacial meltwater coming from an unnamed glacier that flowed into the Garnet Creek valley, with a small glacial lake and ice dam evident in aerial photographs from the 1960s (Fig. 6A). Eventually, the ice dam broke as the Patterson Glacier weakened and initiated its retreat from that area, draining the water from the side valley lake by the 1970s (Fig. 6B). However, the shore environs of Patterson Lake adjacent to the now ice-free valley of Garnet Creek and portions of the nearby fjord (Fig. 4C) were heavily scoured by the Patterson Glacier as recently as c. 1990. The presentday ice-free land is dominated by open gravel areas with large granitic boulders interspersed up to the lake edge, and filled in with willow and alder thickets between scattered conifer seedlings and saplings. Of additional interest for lichens was a $50 \mathrm{~m}$ high, north-facing calcareous rock outcrop (investigated at c. $10 \mathrm{~m}$ above the lake) (Fig. 5B \& C). This rock outcrop scoured smooth by ice plunges straight into the lake but contains narrow ledges supporting cryptogamic communities, probably within the Dryas stage of succession. Also investigated was the vegetation community approximately $0.5 \mathrm{~km}$ inland from the younger flood-prone willow and alder thickets at the lake edge where the vegetation transitions to an early-succession forest of taller (5m high) mixed Sitka alder (Alnus viridis ssp. sinuata), willow and Sitka spruce (Picea sitchensis), with occasional rocky openings created from landslides scattered within the forested areas. This area is like the alder stage of Chapin et al. (1994) and represents the oldest post-glacial succession stage investigated.

\section{Species Identification}

For specimens collected and further investigated in the lab, apothecial characteristics were examined by light microscopy on hand-cut sections mounted in water. Thallus and apothecial sections were investigated, and anatomical measurements made in $10 \% \mathrm{KOH}$. Standard chemicals were used for spot-test reactions. Lichen collections from all sites are housed in the 
herbarium of Michigan State University (MSC). Lichen names and authorities follow Index Fungorum (2019).

\section{Results}

The five sites visited represent three stages in the post-glacial succession described by Chapin et al. (1994). The cryptobiotic crust community of lichens at the terminal moraine of the Baird Glacier represents the pioneer stage; the outwash plain at Baird Glacier, the lakeshore and calcareous rock outcrop at Patterson Glacier and the lateral moraine at Muir Glacier are within the Dryas stage; and the mixed alder-conifer dominated area at Patterson Glacier is alder stage vegetation. Table 1 provides a list of species reported from the five sites. The results are not a comprehensive list of all the lichen species present at each site. Here we report only the species collected or those noted in the field, with emphasis on undescribed or rare crustose lichens (See Materials and methods section).

\section{Pioneer stage: Baird Glacier terminal moraine}

The most frequently encountered lichen species on both the sand of the outwash plain and the terminal moraine (Fig. 3B) are Micarea incrassata and Protopannaria pezizoides. Also present on the terminal moraine were several species considered rare worldwide (e.g., Arthrorhaphis alpina, Peltigera extenuata, Placopsis fusciduloides and Protothelenella sphinctrinoidella). Also present here were three undescribed species of Placopsis, one of which (Placopsis sp. A), with a thallus completely dissolved into soredia, is currently known only from this locality, whereas the other two (Placopsis spp. B \& C) are found in other locations near glaciers or outside this habitat, often on recently exposed surfaces. All three species of Placopsis will be formally described elsewhere (Fryday et al. in prep. and Resl et al. in prep.).

Another previously undescribed species was discovered on loose rocks and cobbles on the moraine's slope facing the glacier (Fig. 3C) and was described as Sagiolechia bairdensis by Fryday \& Dillman (2021). Also collected from this recently exposed area was Micarea erratica, which is new to Alaska (cf. Fryday \& Dillman 2021).

\section{Pioneer/Dryas stage: Patterson Glacier, sand and rocks near lake}

Granitic rocks along the lakeshore that frequently experience disturbance from ice and fluctuating water levels (Fig. 5D) were dominated by Ionaspis lavata and Scoliciosporum umbrinum, two species that frequently colonize this habitat and were also frequent at Baird Glacier. Of particular interest at this site was the flushed, calcareous (marble) rock outcrop adjacent to the lake (Fig. 5C) that, among other species, supported Amygdalaria subdissentiens, Lempholemma radiatum, Placynthium tantaleum and Sporodictyon terrestre. Bryophytes and small marble stones on a narrow ledge near the base of this outcrop supported (among others) Arctomia delicatula, Fuscopannaria mediterranea, Lathagrium undulatum var. granulosum (syn. Collema undulatum var. granulosum Degel.), 
Lempholemma radiatum, Rostania ceranisca (syn. Collema ceraniscum $\mathrm{Nyl}$.) and the recently described Placynthium glaciale that was also present at the Muir Glacier site.

\section{Dryas-stage: Muir Glacier.}

The site investigated was dominated by Dryas drummondii and lichens of the genus Stereocaulon, with numerous small crustose species on soil and overgrowing terricolous bryophytes. Bacidia bagliettoana was especially common but other, less frequent species included Biatora subduplex, Epilichen scabrosus, Gyalidea subscutellaris (first North American record; cf. Spribille et al. 2020), Micarea ternaria, Multiclavula corynoides, Sporodictyon terrestre and Verrucaria xyloxena, whereas rocks supported, among others, Oxneriaria mashiginensis (syn. Aspicilia mashiginensis (Zahlbr.) Oxner), Placopsis cribellans, P. fusciduloides, P. gelida s. str., and an undescribed species of Placopsis with dark, linear soralia (Placopsis sp. C) that has also been collected from recently exposed rock in non-glacial habitat, and Placynthium glaciale.

\section{Dryas-stage: Baird Glacier, outwash plain}

On the stable sands and boulders of the outwash plain, species of genera that contain nitrogen-fixing cyanobacteria (e.g., Peltigera and Stereocaulon) were quite abundant. Species present included Peltigera britannica, P. kristinssonii, P. polydactylon, Sterocaulon alpinum, S. coniophyllum, S. glareosum, S. intermedium, S. paschale and S. saviczii along with terricolous bryophytes (Fig. 3D). Shorebirds are frequent near the Baird Glacier as evidenced by a specimen of Vezdaea acicularis collected from bryophytes on a eutrophicated, prominent bird perch boulder.

\section{Alder-stage: Patterson Glacier, alder-spruce small trees}

The corticolous lichen biota consisted of species frequently found in SE Alaska forests (e.g., Gyalideopsis epicorticis, Loxosporopsis corallifera, Micarea cinerea), but also included less often reported species such as Ochrolechia montana and Pertusaria glaucomela. The saxicolous biota occurring within the alder and spruce forest, although mainly composed of common species (e.g., Amygdalaria consentiens, A. pelobotryon, Rhizocarpon lavatum and $R$. reductum also included some less frequently encountered species (e.g., Bellemerea diamarta, Sporodictyon cruentum, S. terrestre and Steineropsis alaskana).

\section{Other Sites Visited}

The second author made a brief, follow-up visit to Patterson Glacier in 2019 and accessed a recently deglaciated area close to the glacier terminus via kayak. Time to collect and photograph lichens from the terminal and lateral moraines closest to the glacier was minimal and so the species reported from this site (Table 2) are not included in the comparative analysis below. Interestingly, all of the species, except three, have a cyanobacterium as the 
primary photobiont or as an additional obligate symbiont (in cephalodia). This is significant because cyanobacteria fix atmospheric carbon and nitrogen, and these elements are essential for the successful colonization of bare rock surfaces (Schneider et al. 2016).

In 2017, the second author briefly visited the terminal moraine of the Oasis Glacier, a large tributary glacier of Baird Glacier. The retreating Oasis Glacier has exposed an area of rocky terrain surrounded by ice from the Baird and Oasis glaciers $\left(57.188187^{\circ} \mathrm{N}\right.$, $\left.132.634192^{\circ} \mathrm{W}\right)$. This area is at a significantly higher altitude than the other sites visited $(625$ $\mathrm{m}$ ) and several species not documented at other sites were recorded (Table 2). Among these were Circinaria contorta (confirmed by ITS sequence), usually a species of calcareous rocks but here growing lichenicolous on Tingiopsidium elaeinum, and Caloplaca nivalis, an arctic species at its southernmost known locality in Alaska.

\section{Comparison between sites.}

Of the 111 species reported from the five sites, 88 (79.3\%) were reported from only one site, 17 species from two sites, five species (Placopsis fusciduloides, Protopannaria pezizoides, Sporodictyon terrestre, Stereocaulon glareosum and Tingiopsidium elaeinum) from three sites, one (Stereocaulon coniophyllum) from four, and none from all five (Table 3 ). To some extent, this dearth of species common to more than one site can be attributed to the non-quantitative nature of this preliminary investigation (see Materials and methods section). However, all the least common species were noted, and others where it was not possible to identify in the field were collected. Therefore, nearly all the species characteristic of recently deglaciated terrain would have been accounted for in the areas investigated.

The alder-spruce forest site at Patterson Glacier had the highest percentage of unique species (19 out of $24 ; 79.2 \%$ ), followed by the sites at Muir Glacier $(29 / 41 ; 70.7 \%$ ) and the terminal moraine at Baird Glacier $(23 / 39 ; 59.0 \%)$. Patterson Glacier lakeshore $(13 / 25 ; 52.0 \%)$ and the Baird Glacier outwash plain $(5 / 12 ; 41.7 \%)$ had the lowest percentage of unique species. The low percentages of unique species at Patterson Glacier lakeshore was probably because it is a transitional pioneer-Dryas stage community, both of which were more thoroughly investigated at Baird and Muir Glaciers (Table 3), and at the Baird outwash plain because only a low number of species were documented in a very cursory survey. Although Patterson Glacier is the only site where many of the reported species were corticolous from the alder stage, the high percentage of unique species from this site is not attributed to the corticolous substrate because if they are removed from the analysis, the percentage of unique species is even higher $(13 / 16 ; 81.25 \%)$. This probably reflects the fact that the noncorticolous species here are saxicolous, whereas at other sites they are mainly terricolous, and, being less influenced by very recent deglaciation, the lichen biota at the Patterson Glacier sites at Garnet Creek more closely resembles that of the surrounding terrain.

These figures represent a remarkably high disassociation of species between sites and may reflect the rapid changes in ecological succession and environmental conditions present in recently deglaciated terrains. 


\section{Discussion}

\section{Threats to the lichen biota}

Given the current rate of recession, some glaciers will eventually disappear (Dyurgerov 2005; Zemp et al. 2015), and the ones most at risk are those in tropical and temperate regions (Huss et al. 2017). The glaciers of SE Alaska, which mainly terminate at or near sea-level in a temperate rainforest environment, are clearly in this endangered category. Research suggests that, as the ice retreats, not all the species associated with glaciers will be able to migrate and colonize suitable habitats nearby (Körner, 2005). For example, Losapio et al. (2021) showed that vascular plant diversity would decrease with glacier extinction and about one fourth of plant species would become locally extinct. Losapio et al. (2021) further indicated that those plants most in danger from disappearing glaciers are those of the pioneer communities, which, because these are often facilitators of subsequent communities, will lead to extinction cascades. Cryptogams often dominate these pioneer communities and so these would be disproportionally and negatively affected by glacier extinctions. Consequently, some lichen species in this habitat that are known only from SE Alaska are therefore vulnerable to global extinction. This vulnerability is due to 1) the rapid retreat of the ice, changing the climactic envelope that may inhibit obligate lichen species from propagating, 2) the potential for accelerated vascular plant succession (alder, willow) skipping, or significantly shortening, thpioneer lichen stage, and 3) the melting permafrost under the land where glacial ice once rested will alter landforms (moraines), habitat conditions and species colonization patterns.

\section{Post glacial succession}

The rapid rate of post-glacial vegetation succession in SE Alaska varies temporally and spatially. Chapin et al. (1994) gave the location for their pioneer stage at Muir Glacier only as "north shore of Muir Inlet", but from their map, it appears to be at c. $59^{\circ} 4.0^{\prime},-136^{\circ} 18.0^{\prime}$. The area we describe here was approximately three $\mathrm{km}$ further west from this site, much closer to the terminus of Muir Glacier (Fig. 7), and the abundance of Dryas drummondii and Stereocaulon spp. places it within their Dryas stage. We did not encounter the "black crust" described by Worley (1973) as a frequent component of the pioneer stage at Glacier Bay, although it was observed at Baird Glacier (see below), because the site we investigated at Muir Glacier had already passed through the pioneer stage. The "black crust" containing sites reported by Worley are $10 \mathrm{~km}$ further away from the present glacier terminus, are now dense alder thickets.

Also indicative of this rapid rate of succession is the corticolous lichen community present on trees in the alder stage at Patterson Glacier. Aerial photographs indicate this young forested site was covered with ice in 1962 and it remained relatively unvegetated less than 35 years ago (Fig. 6). This site supported species of lichen on Sitka spruce (e.g., Gyalideopsis epicorticis, Ochrolechia montata, Pertusaria glaucomela) that were also reported from mature woodland areas in Glacier Bay NPPr by Spribille et al. (2020). This is a late 
succession alder stage community that has developed in considerably less time than the c. 50 years proposed by Chapin et al. (1994). It is possible that this rapid rate of succession may have been facilitated by the close proximity of older coniferous forests in areas that have been ice-free much longer than the Garnet Creek site. These nearby, older forests undoubtedly support well-developed, corticolous lichen communities, and dispersal of lichen propagules from them to the alder stage forests may be a reason for this enhanced rate of succession. By contrast, the area studied by Chapin et al (1994) at Glacier Bay NPPr is surrounded by alpine tundra (Fig. 2B) with no nearby populations to "seed" the succession to the alder stage.

Worley (1973) investigated the "black crust" phenomenon at Glacier Bay NPPr and recognized its importance in primary colonization because 1) it is composed mostly of cyanobacteria (or cyanobacteria containing lichens), which fix atmospheric nitrogen, 2) the black color is heat-absorbing, which elevates the temperature of the underlying soil, and 3) it has soil-binding properties, which promotes substrate stability. All three of these properties are essential to the subsequent stages of vascular plant succession. Worley (1973) described one type of "black crust" as consisting mainly of the lichen Lempholemma radiatum and although we did not see this species at Muir Inlet, it was observed at other places in Glacier Bay NPPr (Spribille et al. 2020) as individual thalli on bare soil or on rocks. Nowhere at Glacier Bay NPPr was it observed forming the more or less continuous crust described by Worley, although that phenomenon has been observed by the first author on recently disturbed soil beside a dirt access road at the Ben Lawers National Nature Reserve in Scotland, UK. We also observed Lempholemma radiatum on the flushed, calcareous rock outcrop and the sparsely vegetated ledges at Patterson Glacier, suggesting that it is a pioneer species. Placing this latter site within the post-glacial succession is somewhat problematic. The presence of L. radiatum suggests it is pioneer stage but other species (e.g., Placynthium glaciale, Sporodictyon terrestre) that are present in the Dryas stage at Muir Glacier suggest it is more appropriately assigned to the Dryas stage. It is probable that this site represents a transition stage along the continuum between the pioneer and Dryas stages of post-glacial succession

From a lichenological point of view, the pioneer stage is arguably the most exciting stage of the post-glacial succession for making new or rare species discoveries. It is within this stage that cryptogams form the dominant component of the terrestrial biota and where the crucial biotic associations occur that initiate colonization of the newly exposed surface. This is the textbook "primary succession" but the species and their interactions are poorly understood because this stage is usually largely overlooked in ecological studies that concentrate primarily on vascular plant succession (e.g., Chapin et al. 1994; Jones and Henry 2003; Jones and de Moral 2005).

\section{Where do the lichens originate?}


There are several possible sources of the lichen propagules that colonize the newly exposed terrain revealed by a retreating glacier, and it is probable that more than one, if not all, play a part, with different species arriving by different means:

1) Air-borne dispersal, either from the surrounding vicinity or by long-distance dispersal: This is the most obvious, and probably most frequent, means of colonization and may account for many species that are also common in the surrounding area but which are inaccessible for lichen investigations. It is also probable that lichen propagules are transported to SE Alaska from further afield, perhaps even as far away as eastern Asia.

2) On alpine rocks carried with the ice and left on the moraine: There appears to be little evidence of this phenomenon, but it is a possible source of lichen colonization by alpineoccurring species rolling onto the ice and carried to the terminus. Just as likely, however, is the air-borne dispersal of alpine propagules by catabatic winds. For example, one of the previously undescribed species, Sagiolechia bairdensis, was discovered on a small boulder embedded in glacial till on the glacier-facing side of the terminal moraine at Baird Glacier (Fig. 3C) that would have been exposed only since the rapid retreat of the glacier commenced 2-3 years previously. Was the boulder with its associated lichen transported down from higher elevation by the glacier, or has the lichen colonized the boulder in situ?

3) Imported from distant localities by birds: Arctic terns (Sterna paradisaea Pontoppidan), which migrate from southern South America each summer, are frequent at Baird Glacier and other glaciers in the region. Significantly, the nearest known relative of the undescribed sorediate Placopsis A from Baird Glacier is P. pycnotheca I.M. Lamb (T. Spribille, pers. comm.), which occurs on glacier forelands in southern Chile (de los Ríos et al. 2011). Transequatorial migratory birds have been shown to carry bryophyte and lichen fragments in their plumage (Lewis et al. 2014), and this disjunct distribution of closely related species, from subsequent isolation and speciation, may be a consequence of the environs around glaciers being nesting sites for arctic terns and other trans-equatorial migratory birds.

4) They have been near the glaciers all the time, some dormant below the ice: This is the most intriguing possibility. Lichens are well adapted to survive adverse conditions (e.g., Brandt et al. 2014) and Bjerke (2009) showed that ice-encapsulation actually protects lichens from freezing conditions. Similarly, bryophytes have survived beneath polar ice since before the Little Ice Age (La Farge et al. 2013) and for over 1500 years in an Antarctic moss bank (Roads et al. 2014). Although it is unlikely that the intact lichen symbiosis could survive the extreme pressure and anoxic conditions beneath a glacier, as well as the long-term wetting and lack of oxygen during thawing, it is possible that lichen ascospores (or perhaps thallus fragments) could survive being covered by ice for an extended period. The three species mentioned above (Placopsis sp. A, Placynthium glaciale, Sagiolechia bairdensis) that are known only from this habitat were collected from surfaces that have been ice-free for less than c 40 years. Is it possible that they have survived under the ice for hundreds, if not thousands of years? 


\section{Comparison with areas outside southeastern Alaska}

The lichen biota reported here from glaciers in SE Alaska is substantially different from that recently described from northern Alaska (Kasanke 2019), the European Alps (Bilovitz \& Bilovitz et al. 2014 a \& b, 2015 a, b \& c; Mayrhofer 2014;), Svalbard (Wietrzyk et al. 2017; Wietrzyk-Pełka et al. 2018), southern South America (de los Ríos 2011; Garibotti et al. 2011) or Antarctica (Purvis et al. 2013). Much of the differences can be explained by the low altitude and hyper-oceanic climate of the recently deglaciated areas we studied: those at Baird and Muir Glaciers being at sea-level and that at Patterson Glacier at only c. $100 \mathrm{~m}$. The studies by Kasanke (2019), Purvis et al. (2013), Wietrzyk et al. (2017) and Wietrzyk-Pełka et al. (2018) were also at a much higher latitude and the species they report are more typical of those found in polar environments. The different species pools available for colonization and the different climatic conditions that prevail at the various sites are also important, but these are, to a large degree, a consequence of the glacier's altitude and latitude.

In North America, the lichen biota of recently deglaciated terrain is virtually unknown. Elsewhere in Alaska, most studies of glaciers that have included lichens have focused on their use in dating rock surfaces through lichenometry (Calkin \& Ellis 1980, 1981; Loso et al. 2014b). Viereck (1966), who studied post-glacial succession at the Muldrow Glacier in what is now Denali NPPr, was one of the few researchers to include lichens in his vegetation analysis. He lists 17 species of macrolichens, although none had more than 5\% cover, and his inclusion of Stereocaulon paschale and Dryas drummondii in his pioneer stage indicates that he combined the pioneer and Dryas stages later described by Chapin et al. (1994) into this community. In addition, a recent study by Kasanke (2019) describes the lichen species present in a post-glacial succession in the Brooks Range of northern Alaska, but the lichen biota described there is also very different from that described from SE Alaska. Fahselt et al. (1988) studied initial colonization of saxicolous lichens in the vicinity of a receding glacier at Sverdrup Pass, Ellesmere Island, although Jones and Henry (2003) studying primary plant succession on recently deglaciated terrain at Alexandra Fjord (c. $85 \mathrm{~km}$ ESE of Sverdrup Pass) stated categorically that "lichens were not present". Elsewhere in North America, despite the abundance of this habitat in the northern Rocky Mountains and beyond, recently deglaciated terrain has rarely been studied for its lichen biota. For example, the receding glaciers in the Torngat Mountains of northern Labrador (Way et al. 2014, 2015; Pelto 2015) have never been investigated for their lichen biota and neither have those in southern Baffin Island (Paul \& Svoboda 2009; Svoboda \& Paul 2009). Way et al. (2015) make extensive use of lichenometry in dating the rate of glacial recession of the Torngat glaciers but mention only one lichen species, Rhizocarpon geographicum (L.) DC., and state that little else is present in the way of vegetation.

\section{Similar Habitats}

Although not associated with glaciers, in terrain associated with semi-permanent or prolonged snow-lie the ground is covered with snow or ice for much of the year but is 
exposed to warm temperatures for a short period each summer. In these settings, a stable community of plants and cryptogams develops that is adapted to a short-growing season and almost constant seasonal moisture. Vegetation communities are dominated by cryptogams and dwarf plants occurring in the same place each year with little change in successional patterns (Flock 1978; Fryday 2001). This is different from the situation in the vicinity of receding glaciers where fresh terrain is continually being exposed due to rapid ice retreat. The terrain is colonized first by cryptogams and later by various stages of vascular plant communities, and in most places, eventually becomes a forest. In summary, the crucial difference being that with non-glacier, snow-bed vegetation the same terrain is exposed and then covered for a prolonged time each winter and a stable zonation of vegetation communities persists from year to year. This is unlike the dynamic succession of plant and cryptogamic communities the develop on recently deglaciated terrain.

It has been known for over 100 years that distinct vegetation develops in areas that are subject to prolonged snow or ice cover (Vestergren 1902). The vegetation of these areas in Scandinavia was studied in detail by Gjaerevoll (1956) and in North America, the vascular plant vegetation associated with an area of prolonged snow-lie in Wyoming was studied by Billings \& Bliss (1959). However, neither of these authors paid much attention to cryptogams: Billings \& Bliss cite only one bryophyte, Polytrichum juniperinum Hedw., and dismiss lichens with the statement "No lichens, except crustose forms on rocks, were observed in the snowbank area." (Billings \& Bliss 1959).

Literature on the lichen biota associated with area of prolonged snow-lie is sparse. In Europe, the lichens around a nivation hollow in the Cairngorm Mountains of Scotland was studied by Gilbert and Fox (1985) and the habitat in Scotland was studied in detail by Fryday (1997, 2001). Although semi-permanent snow-beds are frequent in North America, the literature documenting the lichen biota of the habitat is equally scant. They were first studied by Flock (1978) on the Niwot Ridge in Colorado, with the only subsequent study appearing to be that by Benedict $(1990,1991)$, also in Colorado. Elsewhere the only mention appears to be from northeastern North America, where Hinds et al. (2010) describe two areas on Katahdin, Maine that are subject to late snow-lie and list several lichens that are characteristic of the habitat.

\section{Conclusion}

The apparent uniqueness of the lichen biota of the recently deglaciated terrain of SE Alaska is probably largely a result of the low altitude and hyper-oceanic climate of the sites investigated; the average rainfall in most of the region is between c. 1000-2500 mm annually and there are also long periods of snow-free exposure due to the temperate rainforest biome. The lichen biota near retreating glaciers is worthy of a more rigorous examination because glaciers are relatively rare in temperate regions of the world and are disproportionally at risk of disappearing due to global warming. Also indicative of this habitat's importance and uniqueness is the presence of at least three species presently appearing to be glacier environs 
obligates: Placopsis sp. A (Baird), Placynthium glaciale (Muir and Patterson) and Sagiolechia bairdensis (Baird).

The dearth of investigations concerning the lichen biota of recently deglaciated terrain and the related, but distinct, areas of prolonged snow-lie is an omission that should be rectified before these habitats and their associated biotas disappear entirely due to a changing climate, vegetation succession, and human-use pressures.

\section{Acknowledgements}

The first author acknowledges the US Forest Service (Tongass NF) for assistance with transport and subsistence that permitted his participation in this project. We also acknowledge a grant from the National Park Service (Glacier Bay National Park: Park Service (CESU Task \# P11AC90513) to the University of Montana Division of Biological Sciences) and logistic support from Glacier Bay National Park that facilitated access to Muir Glacier. We are greatly indebted to Curtis Björk (Clearwater, BC) for his comments on both a previous version and the final draft of the current paper as well as his assistance with some lichen identifications. Emil Tucker, Frances Biles and Jacob Hofman (USDA Forest Service) are thanked for assistance with maps and aerial photographs. Eliza DiMeglio (Corvallis) is thanked for performing thin-layer chromatography and identifications on many Stereocaulon collections and Tim Wheeler (Missoula) for sequencing the Circinaria contorta collection from Oasis Glacier. Toby Spribille (Edmonton) is thanked for his comments on a draft of this paper and for allowing us to cite his unpublished data on Placopsis phylogeny.

\section{References}

Arendt, A.A. 2011. Assessing the Status of Alaska's Glaciers. Science 332 (6033): 1044-1045.

Benedict, J.B. 1990. Experiments on lichen growth. I. Seasonal patterns and environmental controls. Arctic Alpine Res. 22(3): 244-254.

Benedict, J.B. 1991. Experiments on lichen growth. II. Effects of a seasonal snow cover. Arctic Alpine Res. 23(2): 189-199.

Billings, W.D. and Bliss, L.C. 1959. An alpine snowbank environment and its effects on vegetation, plant development and productivity. Ecology 40: 388-397.

Bilovitz, P.O. and Mayrhofer, H. 2014. Lichenized and lichenicolous fungi from the valley 'Ochsental' (Eastern Alps, Vorarlberg, Austria). Fritschiana 78: 47-51.

Bilovitz, P.O., Wallner, A., Tutzer, V., Nascimbene, J. and Mayrhofer, H. 2014a. Terricolous lichens in the glacier forefield of the Gaisbergferner (Eastern Alps, Tyrol, Austria). Phyton 54(2): 235243.

Bilovitz, P.O., Nascimbene, J., Tutzer, V., Wallner, A. and Mayrhofer, H. 2014b. Terricolous lichens in the glacier forefield of the Rötkees (Eastern Alps, South Tyrol, Italy). Phyton 54(2): 245-250.

Bilovitz, P.O., Nascimbene, J. and Mayrhofer, H. 2015a. Terricolous Lichens in the Glacier Forefield of the Morteratsch Glacier (Eastern Alps, Graubünden, Switzerland). Phyton 55(2): 193-320.

Bilovitz, P.O., Tutzer, V., Wallner, A., Nascimbene, J., and Mayrhofer, H. 2014b. Terricolous lichens in the glacier forefield of the Matscherferener (Eastern Alps, South Tyrol, Italy). Acta ZooBot Austria 150/151: 197-202.

Bilovitz, P.O., Wallner, A., Tutzer, V., Nascimbene, J. and Mayrhofer, H. 2015c. Terricolous Lichens in the Glacier Forefield of the Pasterze (Eastern Alps, Carinthia, Austria). Phyton 55(2): 201-214. 
Bjerke J.W. 2009. Ice encapsulation protects rather than disturbs the freezing lichen. Pl. Biol. (Stuttgart) 11: 227-235.

Brandt, A., de Vera, J.-P., Onofri, S. and Ott, S. 2014. Viability of the lichen Xanthoria elegans and its symbionts after 18 months of space exposure and simulated Mars conditions on the ISS. Int. J. of Astrobiol. 14(3): 411-425.

Briner, J.P., Tulenko, J.P., Kaufman, D.S., Young, N.E., Baichtal, J.F., and Lesnek, A. 2017. The Last Deglaciation. Geogr. Res. Lett. 43(2): 429-448

Calkin, P.E. and Eillis, J.M. 1980. A lichenometric dating curve and its application to holocene glacier studies in the central Brooks Range, Alaska. Arctic Alpine Res. 12: 245-264.

Calkin, P.E. and Eillis, J.M. 1981. A cirque-glacier chronology based on emergent lichens and mosses. J. of Glaciol. 27: 511-515.

Cauvy-Fraunié, S., and Dangles, O. 2019. A global synthesis of biodiversity responses to glacier retreat. Nat. Ecol. Evol. 3: 1675-1685. doi: 10.1038/s41559-019-1042-8

Chapin, F.S., Walker, L.R., Fastie, C.L., and Sharman, L.C. 1994. Mechanisms of Primary Succession Following Deglaciation at Glacier Bay, Alaska. Ecol. Monogr. 64: 149-175.

Cooper, W.S. 1923. The recent ecological history of Glacier Bay, Alaska: the present vegetation cycle. Ecology 4: 223-246.

Decker, H.F. 1966. Plants. In Soil development and ecological succession in a deglaciated area of Muir Inlet. Institute of Polar Studies Report Number 20. Edited by A. Mirskey. Ohio State University, Columbus, Ohio. pp. 73-96.

de los Ríos, A., Raggio, J., Pérez-Ortega, S., Vivas, M., Pintado, A., Green, T.G.A., Ascaso, C. and Sancho, L.G. 2011. Anatomical, morphological and ecophysiological strategies in Placopsis pycnotheca (lichenized fungi, Ascomycota) allowing rapid colonization of recently deglaciated soils. Flora 206: 857-864.

Deng, S., Liu, S., Mo, X., Jiang, L. and Bauer-Gottwein, P. 2021. Polar drift in the 1990s explained by terrestrial water storage changes. Geophysical Research Letters, 48: e2020GL092114. https://doi.org/10.1029/2020GL092114

Dyurgerov, M.B. 2005. Mountain Glaciers are at Risk of Extinction. In Global Change and Mountain Regions: An Overview of Current Knowledge of Advances. Edited by U.M. Huber, H.K.M. Bugmann and M.A. Reasoner. Springer, Dordrecht. pp.177-184.

Fahselt, D., Maycock, P.F. and Svoboda, J. 1988. Initial establishment of saxicolous lichens following recent glacial recession in Sverdrup Pass, Ellesmere Island, Canada. Lichenologist, 20: 253-268.

Fell, S.C., Carrivick, J.L., and Brown, L.E. 2017. The multitrophic effects of climate change and glacier retreat in mountain rivers. Bioscience 67: 897-911. doi: 10.1093/biosci/bix107

Flock, J.W. 1978. Lichen-bryophyte distribution along a snow-cover-soil-moisture gradient, Niwot Ridge, Colorado. Arctic Alpine Res. 10: 31-47.

Fryday, A.M. 1997. Ecology and taxonomy of montane lichens in the British Isles. Ph.D. thesis, University of Sheffield.

Fryday, A.M. 2001. The lichen vegetation associated with areas of late snow-lie in the Scottish Highlands. Lichenologist 33(2): 121-150.

Fryday, A.M. and Dillman, K.L. 2021. Two new species of Ostropales (Lecanoromycetes) and other significant records of lichenized fungi from Southeast Alaska. Bryologist 124: 20-26.

Garibotti, I.A., Pissolito, C.I. and Villalba, R. 2011. Vegetation Development on Deglaciated Rock Outcrops from Glaciar Frías, Argentina. Arctic Antarctic Alpine Res. 43: 35-45. 
Gehrels, G.E, and Berg, H.C. 1994. Geology of southeastern Alaska. In The Geology of North America, Vol. G-1 The Geology of Alaska Chapter 13, The Geological Society of America 451467.

Gilbert, O.L. and Fox, B.W. 1985. Lichens of high ground in the Cairngorm Mountains, Scotland. Lichenologist 17: 51-66.

Gjaerevoll, O. 1956. The Plant Communities of the Scandinavian Alpine snow-beds. Bruns Bokhandel, Trondheim.

Hinds, J.W., Fryday, A.M. and Dibble, A.C. 2010. Bryophytes and lichens of the alpine and subalpine zones on Katahdin, Maine. 3: The lichenized fungi. Bryologist 112: 673-703.

Huss, M., Bookhagen, B., Huggel, C., Jacobsen, D., Bradley, R.S., Clague, J.J., Vuille, M., Buytaert, W., Cayan, D.R., Greenwood, G., Mark, B.G., Milner, A.M., Weingartner, R., Winder, M. 2017. Toward mountains without permanent snow and ice. Earths Future 5: 418-435. doi: 10.1002/2016EF000514

Index Fungorum Partnership 2019. www.indexfungorum.org. Accessed 14 November 2019.

Jones, C.C and del Moral, R. 2005. Patterns of primary succession on the foreland of Coleman Glacier, Washington, USA. Pl. Ecol. 180(1): 105-116.

Jones, G.A. and Henry, G.H.R. 2003. Primary plant succession on recently deglaciated terrain in the Canadian High Arctic. J. Biogeogr. 30: 277-296.

Kasanke, S.A. 2019. Plant Succession in the Arctic Brooks Range: Floristic Patterns from Alpine to Foothills, along a Glacial Chronosequence and Elevation Gradient. MSc thesis: University of Alaska, Fairbanks.

Kaufman, D.S. and Manley, W.F. 2004. Pleistocene maximum and late Wisconsin glacier extents across Alaska, U.S.A. In Quaternary Glaciations -Extent and Chronology. Part II. North America: Developments in Quaternary Science, 2. Edited by J. Ehlers and P. I. Gibbard. Elsevier, Amsterdam. pp. 9-27. doi: 10.1016/s1571-0866(04)80182-9

Körner, C. 2005. The Green Cover of Mountains in a Changing Environment. In Global Change and Mountain Regions. An Overview of Current Knowledge. Berlin: Springer. Edited by U.M. Huber, H.K.M. Bugmann and M.A. Reasoner. Springer, Dordrecht. pp. 367-376.

Lader, R., Walsh, J.E., Bhatt, U.S. and Bieniek, P.A. 2019. Anticipated changes to the snow season in Alaska. elevation dependency, timing and extremes. Int. J. Climatol. 1-19 (on-line). https://doi.org/10.1002/joc.6201

La Farge, C., Williams, K.H. and England, J.H. 2013. Regeneration of Little Ice Age bryophytes emerging from a polar glacier with implications of totipotency in extreme environments. Proc. Natl. Acad. Sci. U.S.A. 110(24): 9839-9844.

Larsen, C.F., Motyka, R.J., Arendt A.A., Echelmeyer, K.A., Geissler P.E., 2007. Glacier changes in southeast Alaska and northwest British Columbia and contribution to sea level rise. J. Geophys. Res. 112: 1-11.

Lawrence, D.B. 1979. Primary versus secondary succession at Glacier Bay National Monument, southeastern Alaska. In Proceedings of the First Conference on Scientific Research in the National Parks. Edited by Robert M. Linn. US Government Printing Office, Washington, DC. pp 213-224.

Lewis, L.R., Behling, E., Gousse, H., Qian, E., Elphick, C.S., Lamarre, J., Bêty, J., Liebezeit, J., Rozzi, R., Goffinet, B. 2014. First evidence of bryophyte diaspores in the plumage of transequatorial migrant birds. PeerJ 2: e424 https://doi.org/10.7717/peerj.424. 
Losapio, G., Cerabolini, B.E.L., Maffioletti, C., Tampucci, D., Gobbi, M. and Caccianiga, M. 2021. The Consequences of Glacier Retreat Are Uneven Between Plant Species. Front. Ecol. Evol. 8: 616562. doi: $10.3389 /$ fevo.2020.616562

Loso, M.G., Arendt, A., Larsen, C F., Murphy, N. and Rich, J. 2014a. Alaska National Park glaciers: what do they tell us about climate change? Alaska Park Science 12: 18-25.

Loso, M.G., Doak, D.F. and Anderson R.S. 2014b. Lichenometric dating of little ice age glacier moraines using explicit demographic models of lichen colonization, growth, and survival. Geogr. Ann. A: Phys. Geogr. 96(1): 21-41.

Markon, C., Gray, S., Berman, M., Eerkes-Medrano, L., Hennessy, T., Huntington, H., Littell, J., McCammon, M., Thoman, R. and Trainor, S. 2018: Alaska. In Impacts, Risks, and Adaptation in the United States: Fourth National Climate Assessment, Volume II. U.S. Edited by D.R.

Reidmiller, C.W. Avery, D.R. Easterling, K.E. Kunkel, K.L.M. Lewis, T.K. Maycock, and B.C. Stewart. Global Change Research Program Washington, DC. pp 1185-1241. doi:

10.7930/NCA4.2018.CH26. https://nca2018.globalchange.gov/chapter/alaska

Marzeion, B., Cogley, J. G., Richter, K., and Parkes, D. 2014. Attribution of global glacier mass loss to anthropogenic and natural causes. Science 345: 919. doi: 10.1126/science. 1254702

McCullough, H.A. 1965. Lichens of the Mendenhall Valley, southeastern Alaska. Bryologist 68(2): 221-226.

Muir, J. 1915. Travels in Alaska. Houghton Mifflin, Boston.

NSIDC 2019. National Snow \& Ice Data Center, Glacier Photo Search: http://nsidc.org/data/glacier_photo/search/. Accessed 14 November 2019.

Paul, F. and Svoboda, F. 2009. A new glacier inventory on southern Baffin Island, Canada, from ASTER data: II. Data analysis, glacier change and applications. Ann. Glaciol. 50(53): 22-31. (https://doi: 10.3189/172756410790595921).

Pelto, M. 2013a. Patterson Glacier retreat, Southeast Alaska. https://glacierchange.wordpress.com/2013/03/04/patterson-glacier-retreat-southeast-alaska/

Pelto, M. 2013b. Baird Glacier retreat initiation Alaska. http://blogs.agu.org/fromaglaciersperspective/2013/09/26/baird-glacier-retreat-initiation-alaska/

Pelto, M. 2015. Mount Caubvick Glacier Retreat, Labrador. https://blogs.agu.org/fromaglaciersperspective/2015/09/01/mount-caubvick-glacier

Purvis, O.W., Convey, P., Flowerdew. M.J., Peat, H.J., Najorka, J. and Kearsley A. 2013. Iron localization in Acarospora colonizing schist on Signy Island. Antarc. Sci. 25: 24-30.

Reiners, W.A., Worley, I.A. and Lawrence, D.B. 1971. Plant diversity in a chronosequence at Glacier Bay, Alaska. Ecology 52: 55-69.

Roads, E., Longton, R.E. and Convey, P. 2014. Millennial timescale regeneration in a moss from Antarctica. Curr. Biol. 24 (6): R222- R223.

Roe, G.H., Baker, M.B., and Herla, F. 2017. Centennial glacier retreat as categorical evidence of regional climate change. Nat. Geosci. 10: 95-99. doi: 10.1038/ngeo2863

Schneider, K., Resl, P. and Spribille, T. 2016. Escape from the cryptic species trap: lichen evolution on both sides of a cyanobacterial acquisition event. Molec. Ecol. 25(14): 3453-3468.

Spribille, T., Fryday, A.M., Perez-Ortega, S., Svensson, M., Tønsberg, T., Ekman, S., Holien, H., Resl, P., Schneider, K., Stabentheiner, E., Thüs, H., Vondrák, J. and Sharman, L. 2020. Lichens and associated fungi from Glacier Bay National Park, Alaska. Lichenologist 51: 61-181. 
Svoboda, F. and Paul, F. 2009. A new glacier inventory on southern Baffin Island, Canada, from ASTER data: I. Applied methods, challenges and solutions. Ann. Glaciol. 50(53): 11-21 (doi: 10.3189/172756410790595912).

Viens, R.J., 2001. Late Holocene climate change and calving glacier fluctuations along the southwestern margin of the Stikine Icefield, Alaska, University of Washington, PhD Dissertation, 160 pp. http://www.scidiv.bcc.ctc.edu/rv/phd/toc.html

Viereck, L. A. 1966. Plant succession and soil development on gravel outwash of the Muldrow Glacier, Alaska. Ecol. Monogr. 36(3): 181-199.

Vestergren, T. 1902. Om den olikformiga snöbetäckningens inflytande pä vegetationen i Sarjekfjällen. Bot. Not. 1902: 241-268.

Way, R.G., Bell, T. and Barrand, N.E. 2014. An inventory and topographic analysis of glaciers in the Torngat Mountains, northern Labrador, Canada. J. Glaciol. 60(223): 945-956. (https://doi.org/10.3189/2014JoG13J195)

Way, R.G., Bell, T. and Barrand, N.E. 2015. Glacier change from the little Ice Age to present in the Torngat Mountains, northern Labrador, Canada. Geomorphology 246: 559-569. DOI: 10.1016/j.geomorph.2015.07.006.

Western Regional Climate Center, 2021a. Web Access for Petersburg, date March 19, 2021 https://wrcc.dri.edu/cgi-bin/cliMAIN.pl?ak7233

Western Regional Climate Center, 2021b, Web Access for Gustavus, date March 19, 2021 https://wrcc.dri.edu/cgi-bin/cliMAIN.pl?ak3475

Wietrzyk-Pełka, P., Otte, V. Węgrzyn, M.H. and Olech, M. 2018. From barren substrate to mature tundra - Lichen colonization in the forelands of Svalbard glaciers. Acta Soc. Bot. Poloniae 87(4): 3599.

Wietrzyk, P., Węgrzyn, M. and Lisowska, M. 2017. Lichen diversity on glacier moraines in Svalbard. Cryptog. Mycol. 38(1): 67-80.

Worley, I.A. 1973. the "Black Crust" phenomenon in upper Glacier Bay, Alaska. N. W. Sci. 47(1): $20-29$.

Zemp M., Frey H., Gärtner-Roer I., Nussbaumer S., Hoelzle M., Paul F., Haeberli W., Denzinger F., Ahlstrøm A., Anderson B., Bajracharya S., Baroni C., Braun L., Càceres B., Casassa G., Cobos G., Dàvila L., Delgado Granados H., Demuth M., Espizua L., Fischer A., Fujita K., Gadek B., Ghazanfar A., Hagen J., Holmlund P., Karimi N., Li Z., Pelto M., Pitte P., Popovnin V., Portocarrero C., Prinz R., Sangewar C., Severskiy I., Sigurdsson O., Soruco A., Usubaliev R., Vincent C. 2015. Historically unprecedented global glacier decline in the early 21 st century. J. Glaciol. 61: 745-762. doi: 10.3189/2015JoG 15J017 


\section{Tables}

Table 1: Species reported from Baird, Muir and Patterson Glaciers. Epiphytic species are indicated by 'c'. (A version of this list with the species arranged alphabetically is available as Supplementary Material).

Table 2. Lichens reported from Oasis and Patterson Glaciers in 2017 and 2019.

Table 3: Shared and unique species reported from Baird, Muir and Patterson Glacier.

\section{Figures}

Fig. 1. Map of southeastern Alaska, showing location of Muir, Baird and Patterson Glaciers. Map was created by the authors using ESRI ArcMap (Version 10.4) and US Forest Service library files: Streams and Glaciers in AK Hydro (2016), Petersburg Alaska.

Fig. 2. Muir Glacier. A, View from upper Muir Inlet, Muir Glacier is on the left, Morse Glacier on the right; B, area surveyed on the north side of upper Muir Inlet adjacent to Muir Glacier.

Fig. 3. Baird Glacier. A, Aerial view looking east; B, terminal moraine; C, unstable area close to glacier; D, stable area furthest from glacier.

Fig. 4. Aerial photograph of terminus and outwash plain of Baird Glacier in 1977. Scale bar = $1 \mathrm{~km}$. US Forest Service, Tongass National Forest. 1977. Tongass National Forest 1:15,840 resource aerial photography collection. Project\# 02030, photo 167620 US Forest Service Alaska, Petersburg, Alaska.

Fig. 5. Patterson Glacier. A, Aerial view looking west; B, un-named valley on south side of glacial lake; C, calcareous rock face by lake; D, lakeshore rocks.

Fig. 6. Patterson Glacier. Aerial images from 1962 (A) and 1977 (B). $\mathbf{\Delta}=$ position of marble cliff face; $=$ position of mature alder-spruce stands. Scale bar $=1 \mathrm{~km}$. US Forest Service Resource Photos 1977 Project 02030 Flightline 1676 photo 179, Tongass National Forest, Petersburg Alaska.

Fig. 7. Upper Muir inlet in Glacier Bay NPPr showing retreat of glacier terminus since 1948 and location of areas visited by Worley (1978), Chapin et al. (1994) and Spribille et al. (2020). Scale bar $=10 \mathrm{~km}$. Base Map from Google Maps (Map data (C2021). 
Table 1: Species reported from Baird, Muir and Patterson Glaciers. Epiphytic species are indicated by 'c'. (A version of this list with the species arranged alphabetically is available as Supplementary Material.)

\begin{tabular}{|c|c|c|c|c|c|}
\hline Taxon & $\begin{array}{c}\text { Baird } \\
\text { (terminal moraine) }\end{array}$ & $\begin{array}{c}\text { Patterson } \\
\text { (lake shore) }\end{array}$ & Muir & $\begin{array}{c}\text { Baird } \\
\text { (outwash plain) }\end{array}$ & $\begin{array}{c}\text { Patterson } \\
\text { (mature } A \ln u s \text { ) }\end{array}$ \\
\hline Arthrorhaphis alpina (Schaer.) R. Sant. & $\mathrm{x}$ & - & - & - & - \\
\hline Aspicilia sp. & $\mathrm{x}$ & - & - & - & - \\
\hline Carbonea vorticosa (Flörke) Hertel & $\mathrm{x}$ & - & - & - & - \\
\hline Cladonia subulata (L.) Weber ex F.H. Wigg. & $\mathrm{x}$ & - & - & - & - \\
\hline Massalongia carnosa (Dicks.) Körb. & $\mathrm{x}$ & - & - & - & - \\
\hline Micarea erratica (Körb.) Hertel, Rambold \& Pietschm. & $\mathrm{x}$ & - & - & - & - \\
\hline Peltigera didactyla (With.) J.R. Laundon & $\mathrm{x}$ & - & - & - & - \\
\hline Peltigera extenuata (Nyl. ex Vain.) Lojka & $\mathrm{x}$ & - & - & - & - \\
\hline Pilophorus cereolus (Ach.) Th. Fr. & $\mathrm{x}$ & - & - & - & - \\
\hline Placopsis sp. A & $\mathrm{x}$ & - & - & - & - \\
\hline Placopsis sp. B & $\mathrm{x}$ & - & - & - & - \\
\hline Porpidia thomsonii Gowan & $\mathrm{x}$ & - & - & - & - \\
\hline $\begin{array}{l}\text { Protothelenella sphinctrinoidella (Nyl.) H. Mayrhofer \& } \\
\quad \text { Poelt }\end{array}$ & $\mathrm{x}$ & - & - & - & - \\
\hline $\begin{array}{l}\text { Pseudephebe minuscula (Nyl. ex Arnold) Brodo \& D. } \\
\text { Hawksw. }\end{array}$ & $\mathrm{x}$ & - & - & - & - \\
\hline Rhizocarpon disporum (Nägeli ex Hepp) Müll. Arg. & $\mathrm{x}$ & - & - & - & - \\
\hline Rhizocarpon grande (Flörke ex Flot.) Arnold & $\mathrm{x}$ & - & - & - & - \\
\hline Rhizocarpon polycarpum (Hepp) Th. Fr. & $\mathrm{x}$ & - & - & - & - \\
\hline Sagiolechia bairdensis Fryday & $\mathrm{x}$ & - & - & - & - \\
\hline
\end{tabular}


Sarcogyne lapponica (Ach. ex Schaer.) K. Knudsen \&

Kocourk

Solorina crocea (L.) Ach.

Stereocaulon sp.

Umbilicaria angulata Tuck.

Umbilicaria hyperborea (Ach.) Hoffm.

Ionaspis lavata $\mathrm{H}$. Magn.

Scoliciosporum umbrinum (Ach.) Lojka

Placopsis fusciduloides D.J. Galloway

Tingiopsidium elaeinum (Wahlenb.) Hafellner \& T. Sprib

Stereocaulon coniophyllum I.M. Lamb

Protopannaria pezizoides (Weber) P.M. Jørg. \& S. Ekman

Lecanora polytropa (Ehrh.) Rabenh. Aggr.

Placopsis cribellans (Nyl.) Räsänen

Placopsis sp. C

Scytinium gelatinosum (With.) Otálora, P.M. Jørg. \& Wedin

Umbilicaria torrefacta (Lightf.) Schrad.

Stereocaulon glareosum (Savicz) H. Magn.

Stereocaulon intermedium (Savicz) H. Magn.

Stereocaulon saviczii Du Rietz

Micarea incrassata Hedl.

Platismatia glauca (L.) W.L. Culb. \& C.F. Culb.

Amygdalaria subdissentiens (Nyl.) Mas. Inoue \& Brodo

\begin{tabular}{|c|c|c|c|}
\hline $\mathrm{X}$ & - & - & - \\
\hline $\mathrm{x}$ & - & - & - \\
\hline $\mathrm{x}$ & - & - & - \\
\hline $\mathrm{x}$ & - & - & - \\
\hline $\mathrm{x}$ & - & - & - \\
\hline $\mathrm{x}$ & $x$ & - & - \\
\hline $\mathrm{x}$ & $x$ & - & - \\
\hline $\mathrm{X}$ & $\mathrm{x}$ & $\mathrm{x}$ & - \\
\hline $\mathrm{x}$ & $\mathrm{x}$ & $\mathrm{x}$ & - \\
\hline $\mathrm{X}$ & $\mathrm{x}$ & $x$ & $x$ \\
\hline & $\mathrm{X}$ & - & $\mathrm{x}$ \\
\hline $\mathrm{x}$ & - & $\mathrm{x}$ & - \\
\hline $\mathrm{x}$ & - & $\mathrm{x}$ & - \\
\hline $\mathrm{x}$ & - & $\mathrm{x}$ & - \\
\hline $\mathrm{X}$ & - & $\mathrm{x}$ & - \\
\hline $\mathrm{X}$ & - & $\mathrm{x}$ & - \\
\hline $\mathrm{x}$ & - & $x$ & $x$ \\
\hline $\mathrm{x}$ & - & - & $x$ \\
\hline $\mathrm{x}$ & - & - & $\mathrm{x}$ \\
\hline $\mathrm{X}$ & - & - & $\mathrm{x}$ \\
\hline $\mathrm{X}$ & - & - & - \\
\hline - & $x$ & - & - \\
\hline
\end{tabular}


Arctomia delicatula Th. Fr.

Fuscopannaria mediterranea (Tav.) P.M. Jørg.

Henrica melaspora (Taylor) Savić \& Tibell

Lathagrium undulatum var. granulosum (Degel.) M.

Schultz \& McCune

Lempholemma radiatum (Sommerf.) Henssen

Peltigera canina (L.) Willd.

Pilophorus sp.

Placynthium nigrum (Huds.) Gray

Placynthium tantaleum (Hepp) Hue

Rostania ceranisca (Nyl.) Otálora, P.M. Jørg. \& Wedin

Tingiopsidium isidiatum (Degel.) Hafellner \& T. Sprib.

Xylographa parallela (Ach.) Fr.

Placynthium glaciale Fryday \& T. Sprib.

Psoroma hypnorum (Vahl) Gray

Sporodictyon terrestre (Th. Fr.) Savić \& Tibell

Stereocaulon alpinum Laurer

Loxosporopsis corallifera Brodo, Henssen \& Imshaug

Sporodictyon cruentum (Körb.) Körb.

*Arthonia stereocaulina (Ohlert) R. Sant.

Bacidia bagliettoana (A. Massal. \& De Not.) Jatta

Biatora meiocarpa (Nyl.) Arnold

Biatora subduplex (Nyl.) Printzen

Cladonia scotteri Ahti \& E.S. Hansen 
**Epilichen scabrosus (Ach.) Clem.

Gyalidea subscutellaris (Vězda) Vězda

Ionaspis sp.

Lecidea s. str. sp.

Melanelia commixta (Nyl.) A. Thell

Micarea ternaria (Nyl.) Vězda

Multiclavula corynoides (Peck) R.H. Petersen

Oxneriaria mashiginensis (Zahlbr.) S.Y. Kondr. \& Lőkös

Peltigera sp.

Pertusaria carneopallida (Nyl.) Anzi ex Nyl.

Pilophorus dovrensis (Nyl.) Timdal, Hertel \& Rambold

Placopsis gelida (L.) Linds. s. str.

Porpidia irrigua Orange

Pyrenopsis cf. reductaTh. Fr.

Rusavskia elegans (Link) S.Y. Kondr. \& Kärnefelt

Staurothele septentrionalis Lynge

Stereocaulon rivulorum $\mathrm{H}$. Magn.

Stereocaulon tomentosum $\mathrm{Th}$. Fr.

Thelignya lignyota (Wahlenb.) P.M. Jørg. \& Henssen

Thelocarpon superellum Nyl.

Trapeliopsis gelatinosa (Flörke) Coppins \& P. James

Umbilicaria proboscidea (L.) Schrad.

Verrucaria xyloxena Norman

$\begin{array}{lll}- & - & \mathrm{x} \\ - & - & \mathrm{x} \\ - & - & \mathrm{x} \\ - & - & \mathrm{x} \\ - & - & \mathrm{x} \\ - & - & \mathrm{x} \\ - & - & \mathrm{x} \\ - & - & \mathrm{x} \\ - & - & \mathrm{x} \\ - & - & \mathrm{c} \\ - & - & \mathrm{x} \\ - & - & \mathrm{x} \\ - & - & \mathrm{x} \\ - & - & \mathrm{x} \\ - & - & \mathrm{x} \\ - & - & \mathrm{x} \\ - & - & \mathrm{x} \\ - & - & \mathrm{x} \\ - & - & \mathrm{x} \\ - & - & \mathrm{x} \\ - & - & \mathrm{x} \\ - & - & \mathrm{x} \\ - & - & \mathrm{x} \\ - & & \\ - & - & \\ - & - & \\ - & - & \end{array}$


Amygdalaria consentiens (Nyl.) Hertel, Brodo \& Mas.

$$
\text { Inoue }
$$

Peltigera britannica (Gyeln.) Holt.-Hartw. \& Tønsberg

Peltigera kristinssonii Vitik.

Peltigera polydactylon (Neck.) Hoffm.

Stereocaulon paschale (L.) Hoffm.

Vezdaea acicularis Coppins

Acarospora sinopica (Wahlenb.) Körb.

Amygdalaria pelobotryon (Wahlenb.) Norman

Bellemerea diamarta (Ach.) Hafellner \& Cl. Roux

Biatora sp.

Cladonia cornuta (L.) Hoffm.

Gyalideopsis epicorticis (A. Funk) Tønsberg \& Vězda

Hymenelia lacustris (With.) M. Choisy

Micarea cinerea (Schaer.) Hedl.

Micarea lignaria (Ach.) Hedl.

Myriospora sp.

Ochrolechia montana Brodo

Pertusaria glaucomela (Tuck.) Nyl.

Porpidia tuberculosa (Sm.) Hertel \& Knoph

Rhizocarpon hochstetteri (Körb.) Vain.

Rhizocarpon lavatum (Ach.) Hazsl.

Rhizocarpon reductum Th. Fr.

Scoliciosporum chlorococcum (Graewe ex Stenh.) Vězda 
Steineropsis alaskana T. Sprib. \& Muggia Verrucaria sp.

TOTAL

\begin{tabular}{ll}
- & $\mathrm{X}$ \\
- & $\mathrm{X}$ \\
\hline 12 & 24
\end{tabular}


Table 2. Lichens reported from Oasis and Patterson Glaciers in 2017

\begin{tabular}{lll}
\hline \multirow{2}{*}{ Oasis } & \multicolumn{1}{c}{ Patterson } \\
\cline { 2 - 3 } & Lateral moraine & Terminal moraine \\
\hline Amygdalaria consentiens & Peltigera ponojensis Gyeln. & Amygdalaria panaeola (Ach.) Hertel \& Brodo \\
*Circinaria contorta (Hoffm.) A. & Placopsis cribellans & $* *$ Catillaria stereocaulorum (Th. Fr.) H. \\
$\quad$ Nordin, Savić \& Tibell & & Olivier \\
Caloplaca nivalis (Körb.) Th. Fr. & Polychidium muscicola (Sw.) Gray & Hymenelia ceracea (Arnold) M. Choisy \\
Lecanora polytropa aggr. & Protopannaria pezizoides & Placopsis cribellans \\
Porpidia flavicunda (Ach.) Gowan & Stereocaulon intermedium & Placopsis fusciduloides \\
Rhizocarpon anaperum (Vain.) Vain. & Stereocaulon sp. nov. & Placopsis sp. C \\
Rhizocarpon hensseniae Brodo & & Porpidia sp. nov. \\
Staurothele septentrionalis & & Psoroma tenue var. boreale Henssen \\
Tingiopsidium elaeinum & & Stereocaulon coniophyllum \\
Tingiopsidium isidiatum & & Stereocaulon intermedium \\
\hline
\end{tabular}


Table 3: Shared and unique species reported from Baird, Muir and Patterson Glacier.

\begin{tabular}{ccccccc}
\hline & Total & $\begin{array}{c}\text { Baird } \\
\text { (terminal } \\
\text { moraine) }\end{array}$ & $\begin{array}{c}\text { Patterson } \\
\text { (lake shore) }\end{array}$ & Muir & $\begin{array}{c}\text { Baird } \\
\text { (outwash } \\
\text { plain) }\end{array}$ & $\begin{array}{c}\text { Patterson } \\
\text { (late-succession } \\
\text { Alnus) }\end{array}$ \\
\hline Total & 111 & 39 & 25 & 41 & 12 & 24 \\
Shared & 23 & 16 & 12 & 12 & 7 & 5 \\
$\begin{array}{c}\text { Unique } \\
\text { Percentage }\end{array}$ & 88 & 23 & 13 & 29 & 5 & 19 \\
unique & $\mathbf{7 9 . 3}$ & $\mathbf{5 9 . 0}$ & $\mathbf{5 2 . 0}$ & $\mathbf{7 0 . 7}$ & $\mathbf{4 1 . 7}$ & $\mathbf{7 9 . 2}$ \\
\hline
\end{tabular}




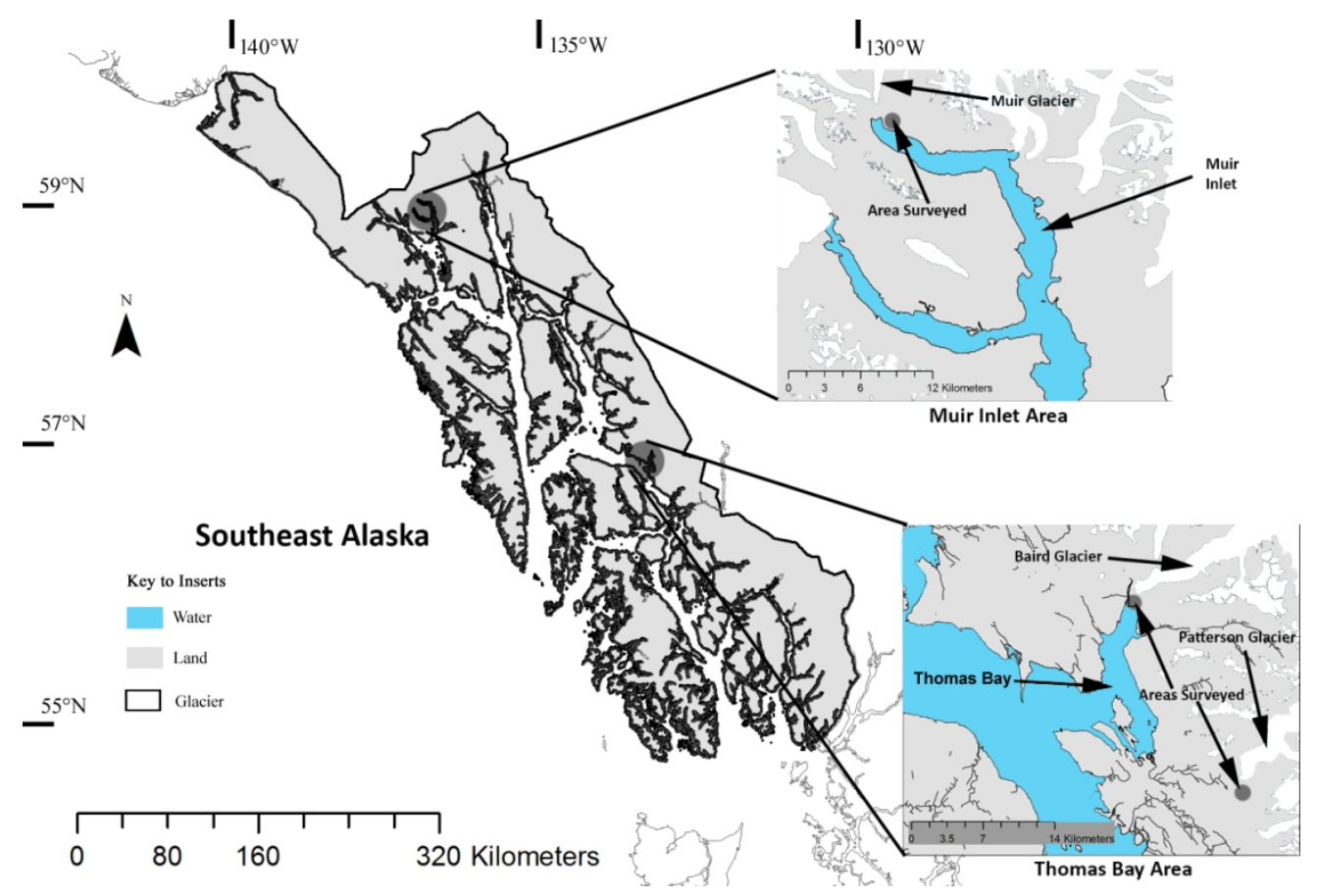

Map of southeastern Alaska, showing location of Muir, Baird and Patterson Glaciers. Map was created by the authors using ESRI ArcMap (Version 10.4) and US Forest Service library files: Streams and Glaciers in AK Hydro (2016), Petersburg Alaska.

$162 \times 110 \mathrm{~mm}(220 \times 220$ DPI $)$ 

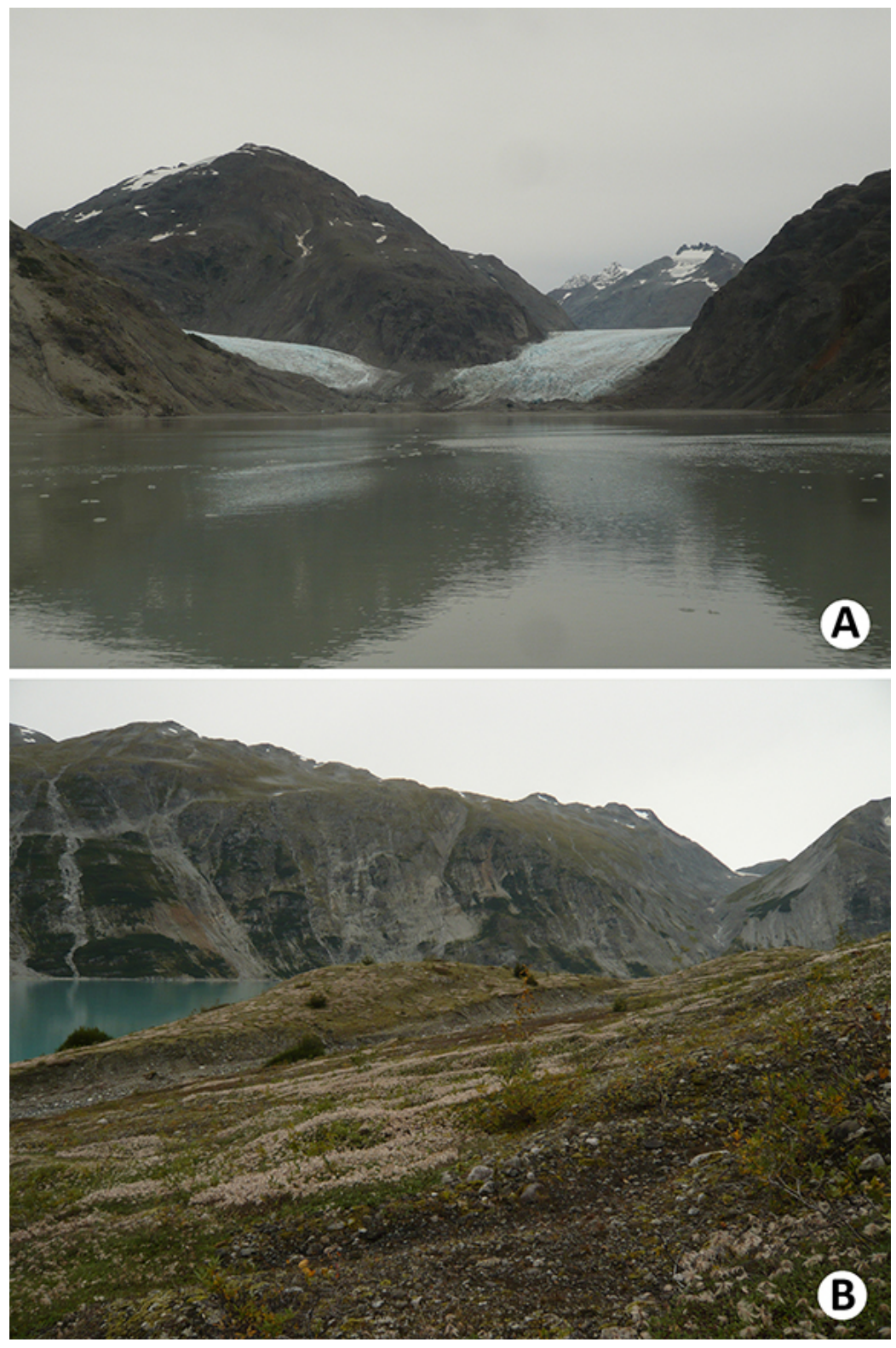

Fig. 2. Muir Glacier. A, View from upper Muir Inlet, Muir Glacier is on the left, Morse Glacier on the right; B, area surveyed on the north side of upper Muir Inlet adjacent to Muir Glacier. 


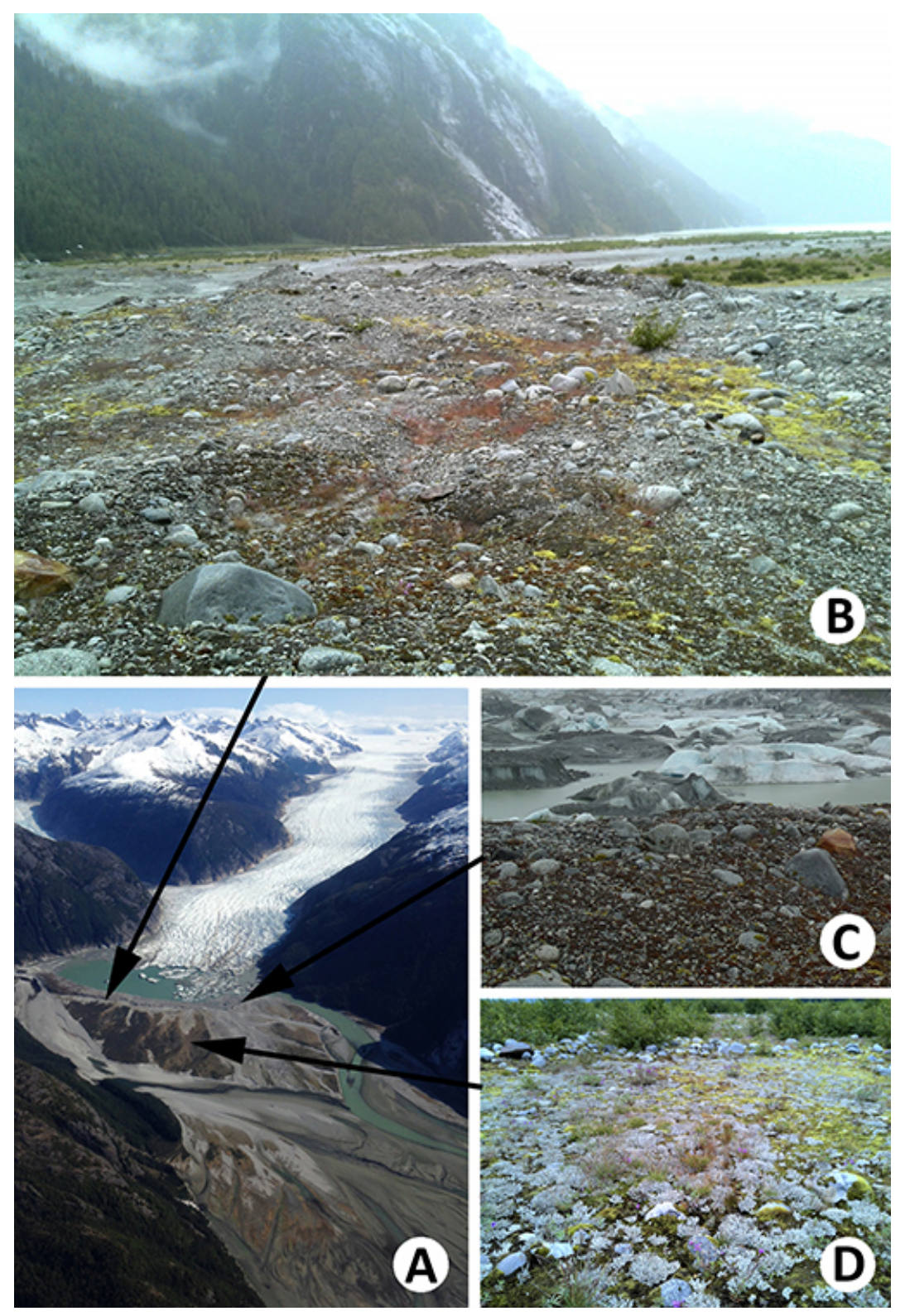

Fig. 3. Baird Glacier. A, Aerial view looking east; B, terminal moraine; C, unstable area close to glacier; $D$, stable area furthest from glacier. 


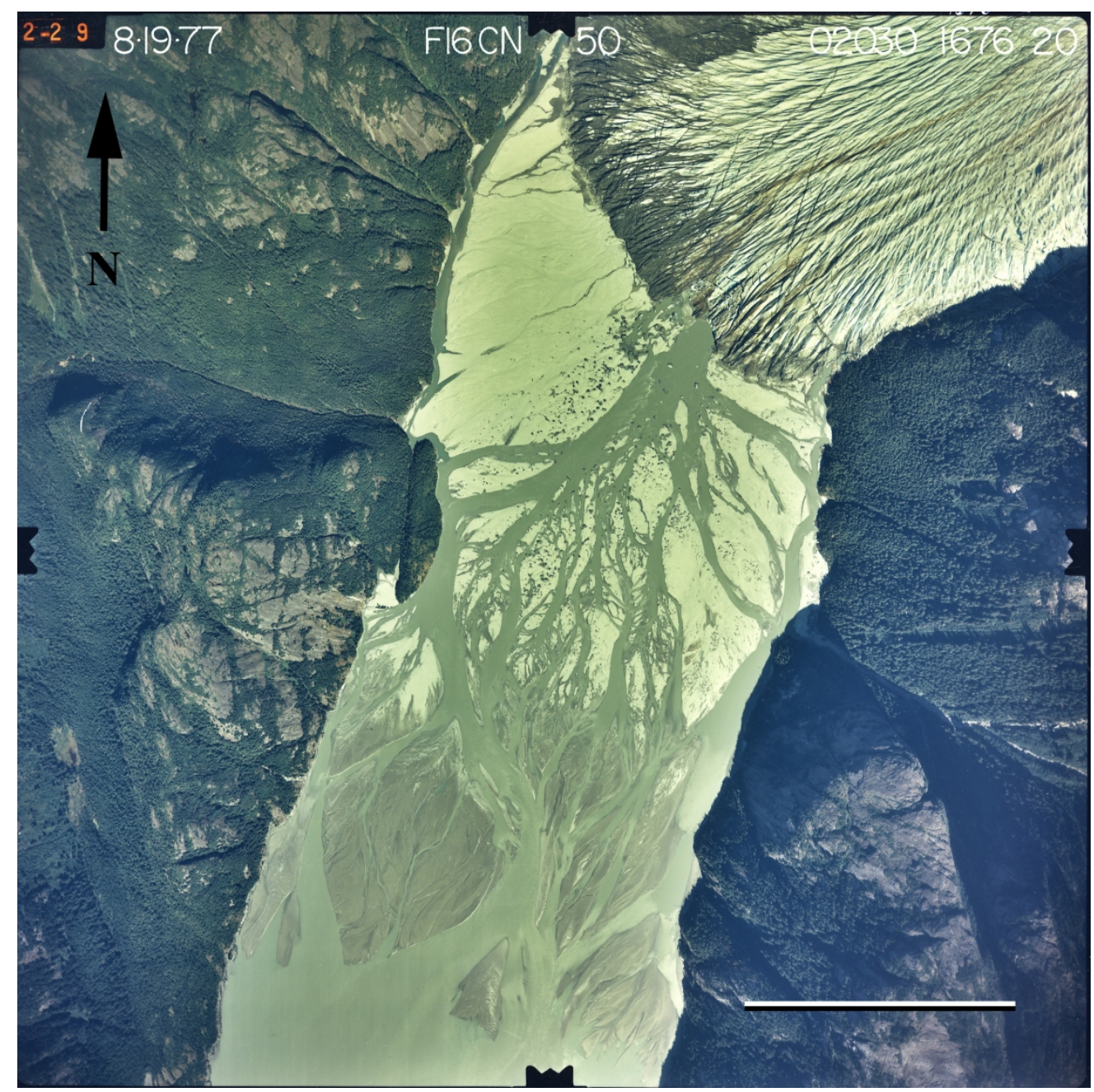

Aerial photograph of terminus and outwash plain of Baird Glacier in 1977. Scale bar $=1 \mathrm{~km}$. US Forest Service, Tongass National Forest. 1977. Tongass National Forest 1:15,840 resource aerial photography collection. Project\# 02030, photo 167620 US Forest Service Alaska, Petersburg, Alaska.

$184 \times 185 \mathrm{~mm}(300 \times 300$ DPI $)$ 

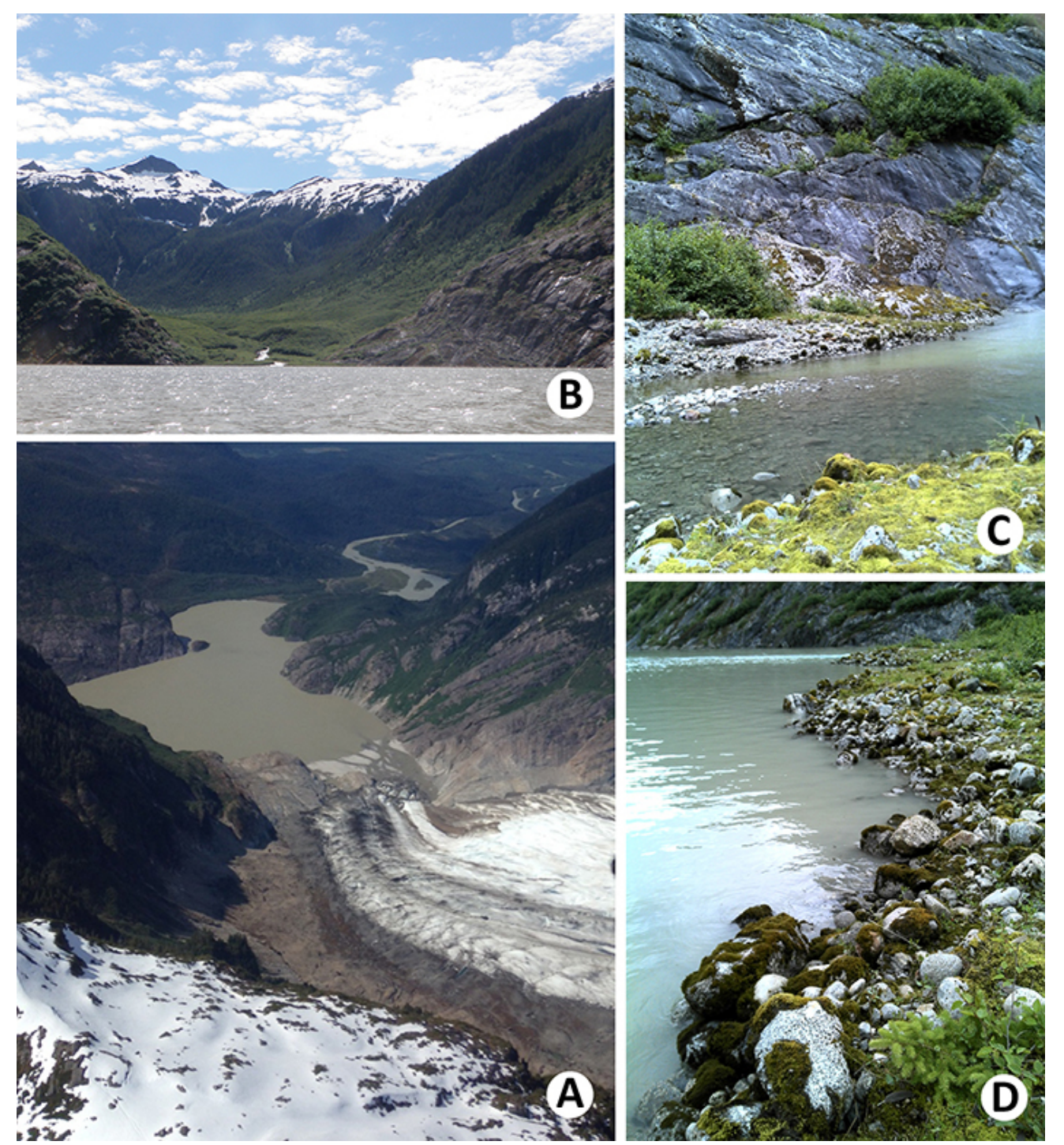

Fig. 5. Patterson Glacier. A, Aerial view looking west; B, un-named valley on south side of glacial lake; C, calcareous rock face by lake; $\mathrm{D}$, lakeshore rocks 

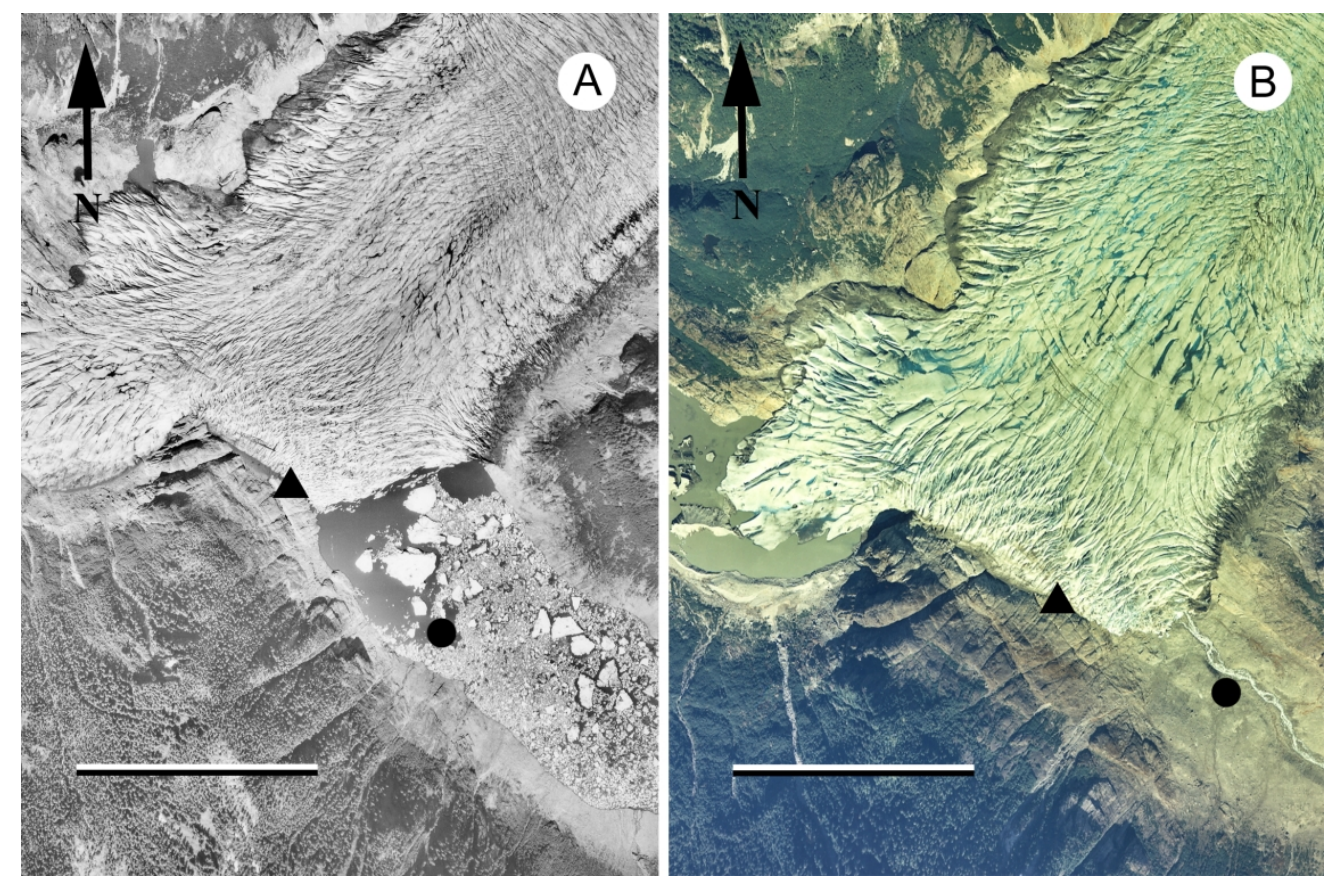

Patterson Glacier. Aerial images from 1962 (A) and 1977 (B). $\square=$ position of marble cliff face; $\square=$ position of mature alder-spruce stands. Scale bar $=1 \mathrm{~km}$. US Forest Service Resource Photos 1977 Project 02030 Flightline 1676 photo 179, Tongass National Forest, Petersburg Alaska.

$188 \times 125 \mathrm{~mm}(300 \times 300$ DPI) 


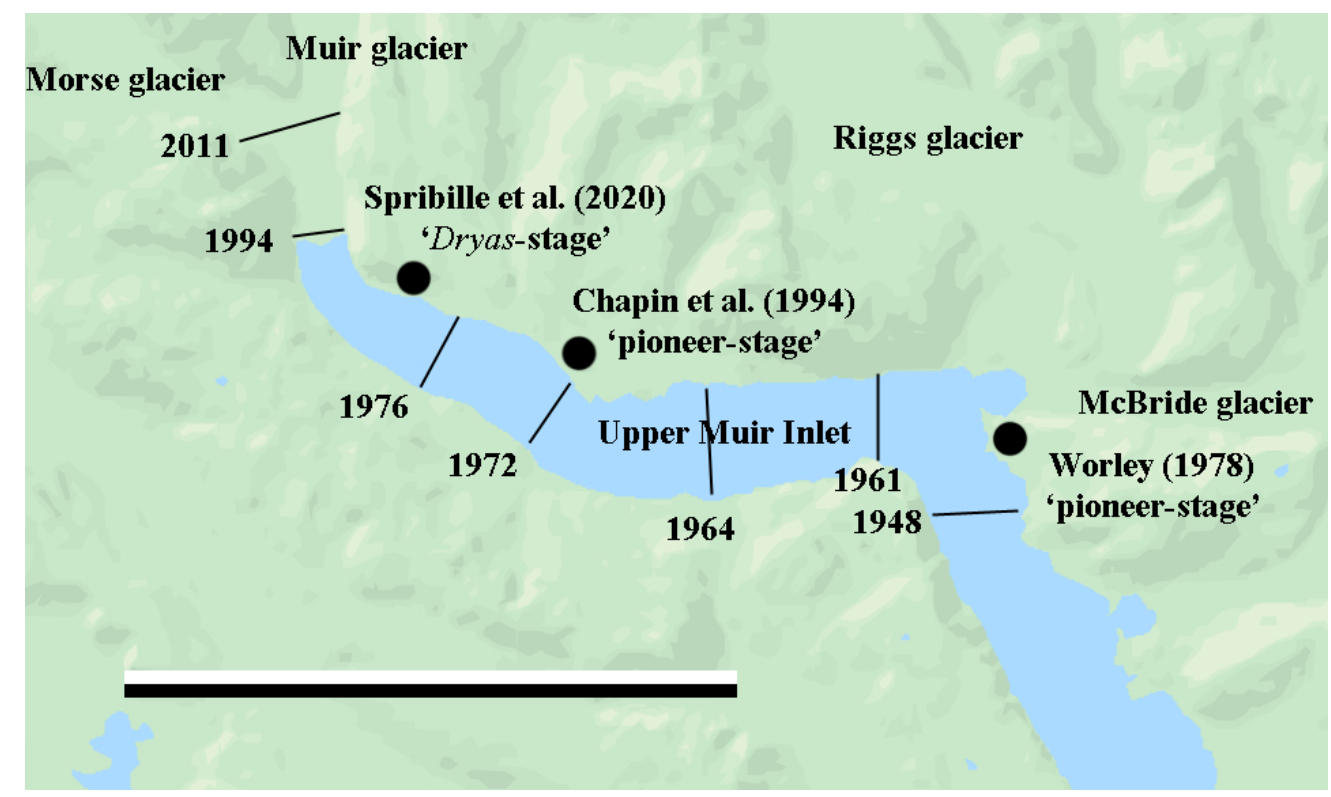

Upper Muir inlet in Glacier Bay NPPr showing retreat of glacier terminus since 1948 and location of areas visited by Worley (1978), Chapin et al. (1994) and Spribille et al. (2020). Scale bar $=10 \mathrm{~km}$. Base Map from Google Maps (Map data (C)2021).

$81 \times 48 \mathrm{~mm}(300 \times 300$ DPI $)$ 